Jan Chocholac - Jaroslava Hyrslova - Tomas Kucera - Stanislav Machalik - Roman Hruska

\title{
FREIGHT TRANSPORT EMISSIONS CALCULATORS AS A TOOL OF SUSTAINABLE LOGISTIC PLANNING
}

The freight transport performance is growing. The transport sector is also one of the largest producers of emissions. This must be reflected not only by production companies but also by other stakeholders. The issue of transport emissions is particularly important for city residents, so today the concept of sustainable city logistics is emphasized. Companies should deal with the amount of produced emissions. The use of emission calculators would support operational, tactical and strategic business decision-making. The aim of this article is to analyse the approaches used in available free calculators of emission arising from the freight transport. The focus was on the transport modes that calculators include, input data, output data and methodologies used to calculate emissions. The method of systematic review was used to search analysed freight transport emissions calculators. The method of content analysis was used to analyse inputs, outputs and freight transport emissions calculator's methodologies. The method of qualitative comparative analysis was used to analyse and compare the freight transport emissions calculators.

Keywords: emission calculator, freight transport, well-to-wheel, tank-to-wheel, well-to-tank

\section{Introduction}

Transport is one of the key factors in development of any modern society, not an objective per se, but a means of economic development and a precondition for achieving the social and regional cohesion. Transport plays an important role in the social and economic development of the state. However, in relation to the environment it is a source of emissions, noise, vibrations and causes health and safety risks and thanks to transport, there is extensive land use [1]. The negative effects of transport on the environment are conditioned by the increasing transport requirements of society in connection with the process of globalization, which is also reflected in demands for transport infrastructure. Thus, the transport has negative impacts on environment for the two basic reasons: the construction of transport infrastructure and the harmful effects of traffic [1-2]. Transport sector influences all the aspects of human life, research, education, trade, entertainment, manufacturing, defence and culture [2].

Sustainable development is an important factor in development of individual economies. Litman [3] states that the concept of sustainable development is built on three pillars - economic, environmental and social. The current trend is to increase traffic efficiency while eliminating its negative impacts. The production of greenhouse gases, especially carbon dioxide, is the most discussed issue that belong to the environmental pillar. As the European Council of Transport Ministers
[4] states, the sustainable development of transport becomes more important in the context of current transport problems, such as:

- unbalanced development of particular modes of transport,

- congestion - as a result of imbalance between modes of transport and the associated bottlenecks in transport infrastructure,

- harmful effects on the environment and public health,

- $\quad$ serious consequences of traffic accidents.

The aim of this article is to analyse the approaches used in free available emission calculators arising from the freight transport. The focus is on the transport modes that calculators include, input data, output data and methodologies used to calculate emissions.

\section{Theoretical background}

Road transport plays an important role in the consumption of energy and the greenhouse gas emissions in the world [5-7]. The greenhouse gas emissions are a global issue [8-9]. Climate change can be attributed to anthropogenic emissions and are expected to increase further in the future [10-11]. In this sense, emissions from transport sectors (land transport, shipping and aviation) significantly contribute to this effect [11-17]. In the case of the road vehicles, overall emissions from

Jan Chocholac ${ }^{1, *}$, Jaroslava Hyrslova ${ }^{1}$, Tomas Kucera ${ }^{2}$, Stanislav Machalik $^{3}$, Roman Hruska ${ }^{1}$

${ }^{1}$ Department of Transport Management, Marketing and Logistics, Faculty of Transport Engineering, University of Pardubice, Czech Republic

${ }^{2}$ Department of Transport Technology and Control, Faculty of Transport Engineering, University of Pardubice, Czech Republic ${ }^{3}$ Department of Informatics in Transport, Faculty of Transport Engineering, University of Pardubice, Czech Republic

*E-mail of corresponding author: jan.chocholac@upce.cz 


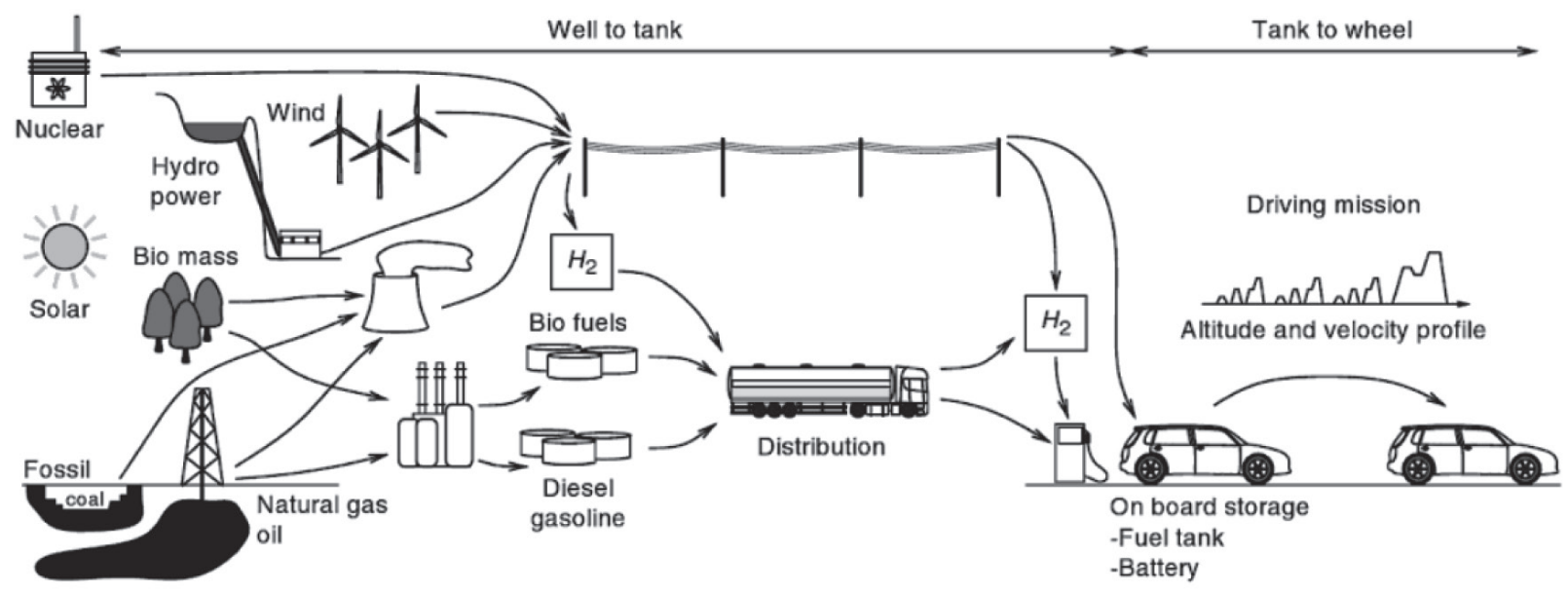

Figure 1 Well-to-Tank and Tank-to-Wheel [3\%]

transport, especially on roads, are one of the main contributors [18-21].

It is well known that the energy consumption in society and emissions of pollutants from transport are affected not only by technical efficiency choice of method and content of carbon and pollutants in the energy sector, but also by the lifestyle and socio-cultural factors [22-23]. Improving the living standard of people will significantly increase energy consumption in the transport sector. In many areas, the environmental and health impacts caused by the transport sector are seriously increasing [24]. The World Economic Forum [25] calculated that the transport and logistics sector was responsible for $5.5 \%$ of total emissions from human activity, at around 2800 mega-tonnes annually. In 2015, the transport sector accounted for approximately $24 \%$ of the worldwide $\mathrm{CO}_{2}$ emissions from fuel combustion [26]. Abbasi and Nilsson [27], Mubarak and Zainal [28] discuss several negative impacts of logistics activities, such as visual pollution, congestion, intimidation, vibration, injuries and accidents.

The issue of the city logistics is addressed in many research areas at present time. New challenges and opportunities of the city logistics to exploit new sources of information are seen with the aim of ensuring sustainable systems primarily for the urban freight transport [29]. Only intelligent city logistics can make a significant contribution to its sustainability. There are many challenges for cities arising from the complex definition of a sustainable freight transport system. It must also ensure access to all modes of the freight transport, while reducing emissions of pollutants and noise and maintaining the economic efficiency of this type of business [30-31].

Reducing the greenhouse gas emissions, of which carbon dioxide is important, has been the major environmental objective for most governments in the developed world [32-33]. Natr [34] notes that carbon dioxide is the most environmentally harmful. He further specifies that several percent $\mathrm{CO}_{2}$ concentrations cause human breathing difficulties. The long-term effects of
$\mathrm{CO}_{2}$ on the human body can lead to fatal consequences. The increase of the concentration of $\mathrm{CO}_{2}$ in the air, considered to be the main cause of global warming, is mainly due to the burning of fossil fuels and the decline of forests [35-36]. The $\mathrm{CO}_{2}$ emissions produced by the road freight transport should therefore be monitored and evaluated. The information obtained can be used to support the decision-making processes at the level of individual transport companies, logistics services providers as well as in the decision-making of state administration bodies and local governments.

European standard EN 16258 Methodology for calculation and declaration of energy consumption and greenhouse gas emissions of transport services (freight and passengers) was approved by the European Committee for Standardisation in 2012 [1, 37]. Currently, there are three main approaches to measuring energy consumption and produced emissions - Well-to-Wheel, Well-to-Tank and Tank-to-Wheel approaches (see Figure 1) [37]:

Well-to-Wheel (sum of total Well-to-Tank and Tank-toWheel) - an approach based on the monitoring of energy consumption and associated emissions production that covers the whole process from the generation of electricity or fuel, through the supply to the appropriate transport means through the distribution network, to the consumption associated with the operation of the means of transport. This approach is based on the sum of Tankto-Wheel and Well-to-Tank values.

Well-to-Tank - energy consumption and production of emissions related to the production of energy or fuel, the indicator covering all activities from the extraction of raw materials through the production of energy or fuel, up to the supply to the respective means of transport through the distribution network. The indicator does not include the transport mode.

Tank-to-Wheel - energy consumption and production of emissions related to the operation of the means of transport. The indicator does not include the next life cycle of the fuel or the transport means. 


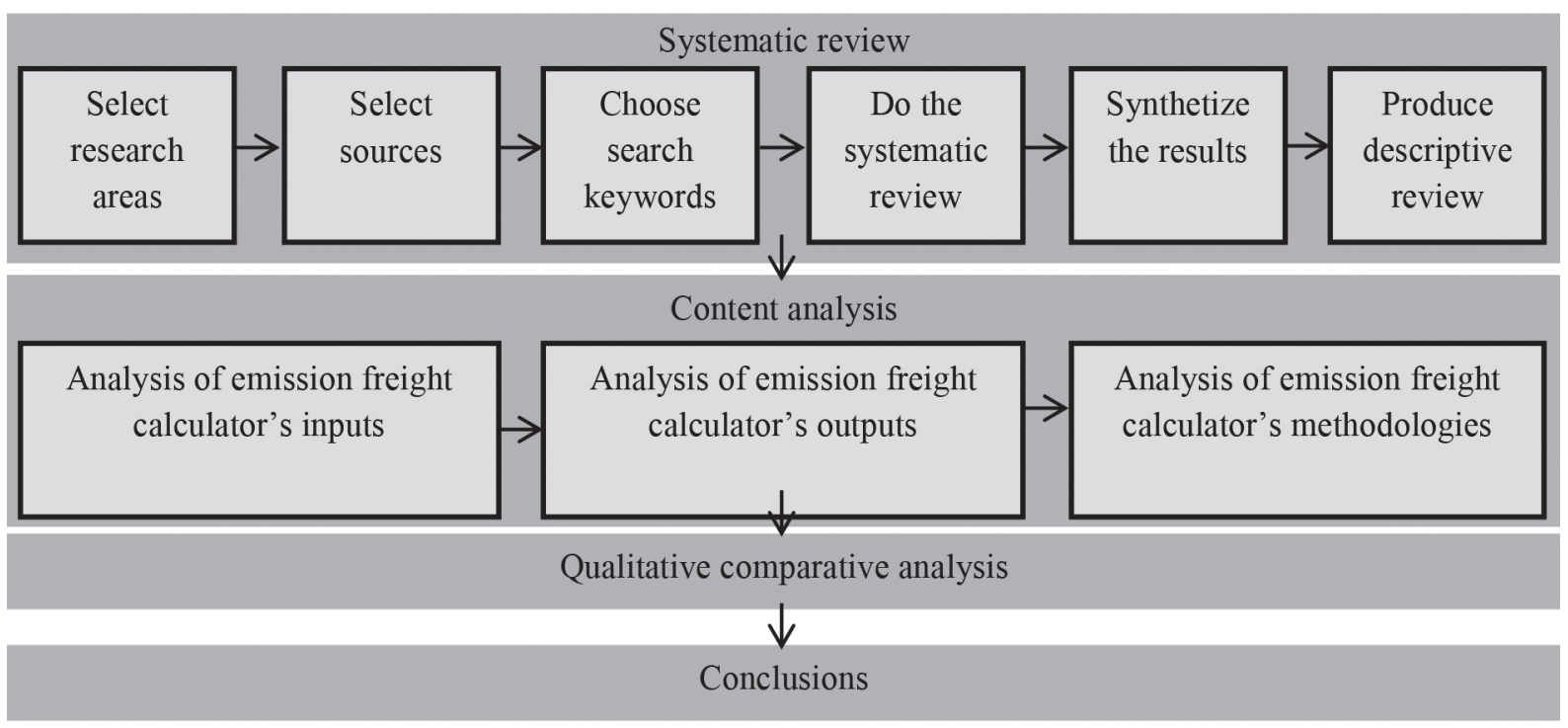

Figure 2 Processing procedure

Scientific methods (systematic review, content analysis, and qualitative comparative analysis), results and discussions are presented in the following sections.

\section{Methods}

The method of systematic review is used to search freight transport emissions calculators. The systematic review method is a systematic, explicit and repeatable procedure designed to identify, evaluate and synthesize the results of researchers, academics and practitioners [38]. The scientific method allows an author of a review to minimize its own personality and influence the content of the text by authors own views [39]. This scientific method is well known and often used by researches, for example [40-42]. The method of systematic review consists of the following steps: select research areas, select sources, choose search terms, do the systematic review, synthetize the results, produce descriptive review [38].

The method of content analysis is used to analyse inputs, outputs and freight transport emissions calculator's methodologies. The method of content analysis is a research technique for making replicable and valid inferences from texts or other meaningful matter to the context of their use [43]. The method of content analysis has been used, for example, in [44-46].

The method of qualitative comparative analysis is used to compare the freight transport emissions calculators obtained using the method of a systematic review. The method of qualitative comparative analysis is a data analysis technique for determining which logical conclusions a data set supports [47]. The qualitative comparative analysis begins with listing all the combinations of variables observed in the data set, followed by applying the rules of logical inference to determine which descriptive inferences or implications the data supports [47]. Figure 2 shows the processing procedure.
The research areas were as follows: "For what transport modes can the emission calculators be used?" and "What inputs, outputs, and methodologies use the freight transport emissions calculators?" The method of systematic review was used to search freight transport emissions calculators. The Google search was used by two independent researchers in January 2019 using the following keywords "emission calculator" and "emission freight calculator". Subsequently, the first ten freight transport emissions calculators were selected based on their position in the search engine. The content analysis of inputs, outputs and methodologies of the freight transport emissions calculators was used by three independent researchers in February 2019.

\section{Results}

Analysed freight transport emissions calculators selected based on their position in the search engine, were: no. 1 - $\mathrm{CO}_{2}$ emission calculator - EECA Business [48], no. 2 - Emission calculator and carbon offset - SAS [49], no. 3 - Emissions Calculator - Cargolux [50], no. 4 - Business $\mathrm{CO}_{2}$ emissions calculator - ClimateCare [51], no. 5 - Freight Emissions Calculator [52], no. 6 - Emission Calculators | Sustainable Freight [53], no. 7 - EcoTransIT World Calculation [54], no. 8 - Van Donge \& De Roo calculator [55], no. 9 - OOCL Carbon Calculator [56], no. 10 - Carbon Calculator I cn.ca [57]. The results of content analysis of the freight transport emissions calculators are presented in Table 1.

The first research area was "For which transport modes can be used emission calculators?" Analysed freight transport emissions calculators can be used for the following modes of transport: six of them for the maritime transport, four of them for the air and road transport, two of them for the railway transport and two of them for the RoRo transport. The RoRo transport is a specific type of maritime transport provided by vessels designed to carry 
Table 1 The results of content analysis

\begin{tabular}{|c|c|c|c|}
\hline No. & $\begin{array}{l}\text { Transport } \\
\text { modes }\end{array}$ & Inputs & Outputs \\
\hline 1 & Unspecified & Fuel type, Amount consumed, Units & $\begin{array}{l}\text { Tonnes of } \mathrm{CO}_{2} \mathrm{e} \\
\text { Energy content (GJ) }\end{array}$ \\
\hline 2 & AiT & $\begin{array}{l}\text { From, To, Cargo weight (kg), Aircraft } \\
\text { type }\end{array}$ & $\begin{array}{l}\text { Great circle distance, Revenue ton } \\
\text { kilometre; Kilograms of } \mathrm{CO}_{2}, \mathrm{NO}_{\mathrm{x}} \text {, } \\
\mathrm{CO}, \mathrm{HC} \text {, Particles, } \mathrm{SO}_{2} \text {; } \\
\mathrm{CO}_{2} \text { offset }\end{array}$ \\
\hline 3 & AiT & From, To, Shipment weight (kg) & Kilometres, Tonnes of $\mathrm{CO}_{2}$ \\
\hline
\end{tabular}

Methodology

Emission factors

of the Ministry

for the Environment

Not specified

Not specified

AiT - Aviation

Emissions and

Offsets; RoT, MaT

- UK Government

conversion factors

U.S. Department

of Energy

Shipment distance (miles)

Tonnes of $\mathrm{CO}_{2}$

CEFIC - Guidelines

Kilograms of $\mathrm{CO}_{2}$, Comparison with another ship

for Measuring and

Managing $\mathrm{CO}_{2}$

Weight (t, TEU), Net weight (t/TEU),

Type of state, Ferry routing, Origin,

7 RoT, RaT, AiT, Destination, Transport mode, Vehicle

Primary energy consumption (MJ,

$\mathrm{kWh}$, diesel equivalents); GHG

emissions $\left(\mathrm{CO}_{2}, \mathrm{CO}_{2} \mathrm{e}, \mathrm{NO}_{\mathrm{x}}, \mathrm{SO}_{\mathrm{x}}\right.$,

NMHC, Particles); Distance (km);

Traction, Load factor, Empty trip factor,

Speed reduction

Port of Loading,

$8 \quad$ MaT

Port of Destination, Volume,

Type of CCWG emission factor

Comparison of transport modes

Methodology Report

(EcoTransIT World

Initiative)

Tonnes of $\mathrm{CO}_{2}$,

Clean Cargo

Distance (km)

Working Group

(CCWG)

$\mathrm{CO}_{2}$ Index $(\mathrm{kg} \mathrm{CO} /$ TEU-km or kg

$\mathrm{CO}_{2} / \mathrm{t}-\mathrm{km}$,

Total distance $(\mathrm{km})$,

$\mathrm{CO}_{2}$ emissions

Clean Cargo

Working Group

(CCWG)

Transport and

Units (miles/km, t), Shipment weight (t),

of Origin, Port of Destination

Tonnes of $\mathrm{CO}_{2} \mathrm{e}$

Environment

Database System

Notes: RoT - road transport, RaT - railway transport, AiT - air transport, MaT - maritime transport, RoRo - Roll-on/roll-off ships, NMHC - Non-methane hydrocarbons, GHG - greenhouse gas

wheeled cargo, such as cars, trucks, semi-trailer trucks, trailers, and railroad cars. A comprehensive multimodal emission calculator has not been found within the analysed calculators. If a user needs to calculate emissions of multimodal transport, transportation must be divided into sections according to the different transport modes. Subsequently, the user has to add the emissions from the individual sections.

The second research area was "What inputs, outputs, and methodologies use the freight transport emissions calculators?" Basic input data of most analysed freight transport emissions calculators was the same or similar, for example: from/origin/port of loading, to/destination/port of destination or direct entry of distance/shipment distance/ flight time. Further data is generally related to the weight of the shipment/cargo, weight/freight weight/volume/cargo volume or the net weight. Some freight transport emissions calculators allow the user to enter additional specific input data, for example: fuel type and amount consumed, type of means of transport (aircraft type/ship type/vehicle type etc.), type of goods (light/average/heavy), cargo type (bulk/ liquid/other), ferry routing, type of traction, load factor, emission standard, empty trip factor and speed reduction. Most calculators allow the user to choose from several units (km/miles/hours, kg/t/lbs/TEU etc.). All analysed calculators contain output data on $\mathrm{CO}_{2}$ emissions (calculators differ only in units). Some calculators also included the following output data: energy consumption; amount of $\mathrm{CO}, \mathrm{HC}, \mathrm{NO}_{\mathrm{x}}$, $\mathrm{SO}_{x}$, NMHC, particles; the possibility of offsetting emissions; total distance and comparison of transport modes.

Some freight transport emissions calculators do not specify the calculation methodology used. Other freight transport emissions calculators are based on the following approaches: Emission factors of the Ministry 
for the Environment; Aviation Emissions and Offsets; UK Government conversion factors; U.S. Department of Energy; CEFIC - Guidelines for Measuring and Managing $\mathrm{CO}_{2}$; Methodology Report (EcoTransIT World Initiative); Clean Cargo Working Group or Transport and Environment Database System.

\section{Discussion}

After evaluating all the analysed freight transport emissions calculators, the use of EcoTransIT World calculator can be recommended, because that is the most comprehensive freight transport emissions calculator. The EcoTransIT World calculator allows choosing between standard and extended versions. The calculator can be used to calculate emissions from the following modes of the freight transport: road transport (truck), rail transport (train), air transport (airplane), sea and maritime transport (sea ship and barge). The EcoTransIT World calculator also allows specifying a large number of input variables and generates a large number of output variables in tabular and graphical form. This calculator distinguishes the type of output emissions (Well-to-Wheel, Well-to-Tank and Tankto-Wheel). It transparently refers to the used methodology - Ecological Transport Information Tool for Worldwide Transports: Methodology and Data Update 2018 developed by IVE mbH - Ingenieurgesellschaft fur Verkehrswesen mbH Hannover, Infras AG -Consulting, Analysis and Research and ifeu - Institut fur Energie - und Umweltforschung Heidelberg GmbH.

Some analysed freight transport emissions calculators are available for one mode of transport only (usually for air transport and maritime transport); some calculators do not have a transparently specified methodology for emissions calculation. Most calculators do not allow specifying input variables sufficiently. Nine out of ten freight transport emissions calculators do not distinguish the approach to measuring emissions (Well-to-Wheel, Well-to-Tank and Tank-to-Wheel) as the output variable.

The big problem is the fact that the analysed freight transport emissions calculators do not allow the user to easily calculate the emissions of the multimodal transport, because multimodal transport consists of several modes of transport. If a user needs to calculate emissions of multimodal transport, transportation must be divided into sections according to the different transport modes.

The limit of the research is the number of freight transport emissions calculators studied, because only ten emission calculators were studied. Therefore, all conclusions are valid only for these ten freight transport emissions calculators. On the other hand, it is necessary to emphasize that these freight transport emissions calculators are the best positioned in the Google search engines after entering defined keywords.

\section{Conclusion}

The issue of the freight transport emissions is a very actual issue. This issue is addressed not only by researches but by companies, as well. Some companies are profiled as a socially responsible and in the context of their business activities take into account environmental and social aspects of their activities, products and services. Companies integrate environmental and social aspects into the decision-making processes at strategic and tacticaloperational levels and use appropriate management tools to support the decision-making processes. Emission calculators can be included as logistics planning tools. Their use helps companies to reduce the negative environmental impact of logistics processes. The public and other stakeholders (business partners, employees, the state, etc.) are interested in this issue.

Nowadays, the largest companies have their own emission calculators, but most other companies use freely available emission calculators. This was one of the reasons for the analysis. The aim of the article was to analyse the approaches used in free available emission calculators arising from the freight transport. The focus was on the transport modes that calculators include, input data, output data, and methodologies used to calculate emissions. Use of EcoTransIT World calculator is recommended due to its transparency, complexity, structure of inputs and outputs and user-friendliness. On the other hand, it would be very beneficial to create a similar freight multimodal emission calculator that will be comprehensive and will cover all the emissions resulting from the implementation of multimodal transport. The results of the analysis could also be used to create new types of emission calculators. In the future, emission calculators should become a commonly used logistics planning tool, not only in logistics companies, but also in all the small, medium and large companies, regardless of the business branch. Appropriate tools should also be used at the level of the state administration and local governments as a support to the decision-making processes. The use of these tools could contribute to changing the approach to logistics planning, both within companies and supply chains, as well as within cities, conurbations and regions.

\section{Acknowledgement}

This article is published within realization of the project "Cooperation in Applied Research between the University of Pardubice and companies in the Field of Positioning, Detection and Simulation Technology for Transport Systems (PosiTrans)", registration No.: CZ.02.1.01/0.0/0.0/17_049/0008394. 


\section{References}

[1] PETRO, F., KONECNY, V. calculation of emissions from transport services and their use for the internalisation of external costs in road transport. Procedia Engineering [online]. 2017, 192, p. 677-682. eISSN 1877-7058. Available from: https://doi.org/10.1016/j.proeng.2017.06.117

[2] DANISH, BALOCH, M. A., SUAD, S. Modelling the impact of transport energy consumption on $\mathrm{CO}_{2}$ emission in Pakistan: evidence from ARDL approach. Environmental Science and Pollution Research [online]. 2018, 25(10), p. 9461-9473. ISSN 0944-1344, eISSN 1614-7499. Available from: https://doi.org/10.1007/s11356-018-1230-0

[3] LITMAN, T. A. Sustainable transportation indicators. Sustainable Transportation Indicators Subcommittee of the Transportation Research Board, 2008.

[4] Assessment and decision making for sustainable transport - European Council of Ministers of Transport [online]. Paris Cedex: OECD Publications, 2004. ISBN 92-821-1311-6. Available from: https://www.itf-oecd.org/sites/default/files/ docs/04assessment.pdf

[5] PENG, T., OU, X., YUAN, Z., YAN, X., ZHANG, X. Development and application of China provincial road transport energy demand and GHG emissions analysis model. Applied Energy [online]. 2018, 222, p. 313-328. ISSN 0306-2619. Available from: https://doi.org/10.1016/j.apenergy.2018.03.139

[6] $\mathrm{CO}_{2}$ emissions from fuel combustion highlights 2015 - International Energy Agency, OECD [online]. Paris Cedex: International Energy Agency and Organization for Economic Cooperation and Development, 2015. Available from: https://iea.org/publications/freepublications/publication/CO2EmissionsfromFuelCombustionHighlights2017.pdf

[7] $\mathrm{CO}_{2}$ emissions from fuel combustion highlights 2016 - International Energy Agency, OECD [online]. Paris Cedex: International Energy Agency and Organization for Economic Cooperation and Development, 2016. Available from: https:/emis.vito.be/sites/emis.vito.be/files/articles/3331/2016/CO2EmissionsfromFuelCombustion Highlights_2016.pdf

[8] LlANO, C., PEREZ-BALSAlOBRE, S., PEREZ-GARCIA, J. Greenhouse gas emissions from intra-national freight transport: measurement and scenarios for greater sustainability in Spain. Sustainability [online]. 2018, 10(7), p. 1-33. eISSN 2071-1050. Available from: https://doi.org/10.3390/su10072467

[9] YOON, Y., YANG, M., KIM, J. An analysis of $\mathrm{CO}_{2}$ emissions from international transport and the driving forces of emissions change. Sustainability [online]. 2018, 10(5), p. 1-18. eISSN 2071-1050. Available from: https://doi.org/10.3390/su10051677

[10] STOCKER, T. F., QIN, D., PLATTNER, G.-K., TIGNOR, M., ALLEN, S. K., BOSCHUNG, J., NAUELS, A., XIA, Y., BEX, V., MIDGLEY, P. M. (eds.) Climate change 2013: the physical science basis. Contribution of working group I to the fifth assessment report of the intergovernmental panel on climate change. Cambridge, United Kingdom and New York, USA: Cambridge University Press, 2013. ISBN 978-1-107-05799-1.

[11] HENDRICKS, J., RIGHI, M., DAHLMANN, K., GOTTSCHALDT, K., GREWE, V., PONATER, M., SAUSEN, R., HEINRICHTS, D., WINKLER, Ch., WOLFERMANN, A., KAMPFFMEYER, T., FRIEDRICH, R., KLOETZKE, M., KUGLER, U. Quantifying the climate impact of emissions from land-based transport in Germany. Transportation Research Part D-Transport and Environment [online]. 2018, 65, p. 825-845. ISSN 1361-9209, eISSN 1879-2340. Available from: https://doi.org/10.1016/j.trd.2017.06.003

[12] FUGLESTVEDT, J. S., BERNTSEN, T., MYHRE, G., RYPDAL, K., SKEIE, R. B. Climate forcing from the transport sectors. Proceedings of the National Academy of Sciences of the United States of America [online]. 2008, 105, p. 454458. ISSN 0027-842, eISSN 1091-6490. Available from: https://doi.org/10.1073/pnas.0702958104

[13] EYRING, V., ISAKSEN, I. S. A., BERNTSEN, T., COLLINS, W. J., CORBETT, J. J., ENDRESEN, O., GRAINGER, R. G., MOLDANOVA, J., SCHLAGER, H., STEVENSON, D. S. Transport impacts on atmosphere and climate: shipping. Atmospheric Environment [online]. 2010, 44, p. 4735-4771. ISSN 1352-2310. Available from: https://doi.org/10.1016/j.atmosenv.2009.04.059

[14] LEE, D. S., PITARI, G., GREWE, V., GIERENS, K., PENNER, J. E., PETZOLD, A., PRATHER, M. J., SCHUMANN, U., BAIS, A., BERNSTEN, T., IACHETTI, D., LIM, L. L., SAUSEN, R. Transport impacts on atmosphere and climate: aviation. Atmospheric Environment [online]. 2010, 44, p. 4678-4734. ISSN 1352-2310. Available from: https://doi. org/10.1016/j.atmosenv.2009.06.005

[15] SAUSEN, R. Transport impacts on atmosphere and climate. Atmospheric Environment [online]. 2010, 44, p. 46464647. ISSN 1352-2310. Available from: https://doi.org/10.1016/j.atmosenv.2010.02.033

[16] UHEREK, E., HALENKA, T., BORKEN-KLEEFELD, J., BALKANSKI, Y., BERNSTEN, T., BORREGO, C., GAUSS, M., HOOR, P., JUDA-REZLER, K., LELIEVELD, J., MELAS, D., RYPDAL, K., SCHMID, S. Transport impacts on atmosphere and climate: land transport. Atmospheric Environment [online]. 2010, 44, p. 4772-4816. ISSN 1352-2310. Available from: https://doi.org/10.1016/j.atmosenv.2010.01.002

[17] SAUSEN, R., GIERENS, K., EYRING, V., HENDRICKS, J., RIGHI, M. Climate impact of transport. In: SCHUMANN, U. (Ed.) Atmospheric physics. Background - methods - trends. Berlin, Heidelberg: Springer, 2012. p. 711-725. ISBN 9783-642-30183-4. 
[18] SINGH, V., SAHU, S. K., KESARKAR, A. P., BISWAL, A. Estimation of high resolution emissions from road transport sector in a megacity Delhi. Urban Climate [online]. 2018, 26, p. 109-120. eISSN 2212-0955. Available from: https://doi.org/10.1016/j.uclim.2018.08.011

[19] GURJAR, B. R., RAVINDRA, K., NAGPURE, A. S. Air pollution trends over Indian megacities and their local-toglobal implications. Atmospheric Environment [online]. 2016, 142, p. 475-495. ISSN 1352-2310. Available from: https://doi.org/10.1016/j.atmosenv.2016.06.030

[20] SINGH, V., SOKHI, R. S., KUKKONEN, J. PM2.5 concentrations in London for 2008 - A modelling analysis of contributions from road traffic. Journal of the Air and Waste Management Association [online]. 2014, 64(5), p. 509-518. ISSN 1096-2247, eISSN 2162-2906. Available from: https://doi.org/10.1080/10962247.2013.848244

[21] GUTTIKUNDA, S. K., CALORI, G. GIS Based emissions inventory at $1 \mathrm{~km} \times 1 \mathrm{~km}$ spatial resolution for air pollution analysis in Delhi, India. Atmospheric Environment [online]. 2013, 67, p. 101-111. ISSN 1352-2310. Available from: https://doi.org/10.1016/j.atmosenv.2012.10.040

[22] BRAND, C., ANABLE, J., MORTON, C. Lifestyle, efficiency and limits: modelling transport energy and emissions using a socio-technical approach. Energy Efficiency [online]. 2019, 12(1), p. 187-207. ISSN 1570-646X, eISSN 1570-6478. Available from: https://doi.org/10.1007/s12053-018-9678-9

[23] YANG, C., MCCOLluM, D., MCCARTHY, R., LEIGHTY, W. Meeting an 80\% reduction in greenhouse gas emissions from transportation by 2050: a case study in California. Transportation Research Part D: Transport and Environment [online]. 2009, 14(3), p. 147-156. ISSN 1361-9209, eISSN 1879-2340. Available from: https://doi.org/10.1016/j.trd.2008.11.010

[24] LIU, L., WANG, K., WANG, S., ZHANG, R., TANG, X. Assessing energy consumption, $\mathrm{CO}_{2}$ and pollutant emissions and health benefits from China's transport sector through 2050. Energy Policy [online]. 2018, 116, p. 382-396. ISSN 0301-4215, eISSN 1873-6777. Available from: https://doi.org/10.1016/j.enpol.2018.02.019

[25] Supply chain decarbonization: the role of logistics and transport in reducing supply chain carbon emission - World Economic Forum [online]. Geneva, Switzerland: The Framework of the Logistics and Transport Partnership Programme, 2009. Available from: http://www3.weforum.org/docs/WEF_LT_SupplyChainDecarbonization_ Report_2009.pdf

[26] $\mathrm{CO}_{2}$ emissions from fuel combustion 2017 - International Energy Agency [online]. 2017. Available from: http://www.indiaenvironmentportal.org.in/files/file/CO2EmissionsfromFuelCombustionHighlights2017.pdf

[27] ABBASI, M., NILSEN, F. Developing environmentally sustainable logistics: exploring themes and challenges from a logistics service providers' perspective. Transportation Research Part D: Transport and Environment [online]. 2016, 46, p. 273-283. ISSN 1361-9209, eISSN 1879-2340. Available from: https://doi.org/10.1016/j.trd.2016.04.004

[28] MUBARAK, A., FACHRUDDIN, Y. Development of a framework for the calculation of $\mathrm{co}_{2}$ emissions in transport and logistics in Southeast Asia. International Journal of Technology [online]. 2018, 9(4), p. 787-796. ISSN 2086-9614, eISSN 2087-2100. Available from: https://doi.org/10.14716/ijtech.v9i4.1432

[29] TANigUCHI, E., THOMPSON, R. G., YAMADA, T. New opportunities and challenges for city logistics. Transportation Research Procedia [online]. 2015, 12, p. 5-13. ISSN 2352-1465. Available from: https://doi.org/10.1016/j.trpro.2016.02.004

[30] OSKARBSKI, J., KASZUBOWSKI, D. Applying a mesoscopic transport model to analyse the effects of urban freight regulatory measures on transport emissions - an assessment. Sustainability [online]. 2018, 10(7), p. 1-18. eISSN 20711050. Available from: https://doi.org/10.3390/su10072515

[31] BEHRENDS, S., LINDHOLM, M., WOXENIUS, J. Impact of urban freight transport: a definition of sustainability from an actor's perspective. Transportation Planning and Technology [online]. 2008, 31(6), p. 693-713. ISSN 0308-1060. Available from: https://doi.org/10.1080/03081060802493247

[32] WADUD, Z., CHINTAKAYALA, P. K. Personal carbon trading: trade-off and complementarity between in-home and transport related emissions reduction. Ecological Economics [online]. 2019, 156, p. 397-408. ISSN 0921-8009, eISSN 1873-6106. Available from: https://doi.org/10.1016/j.ecolecon.2018.10.016

[33] LIU, F., ZHAO, F., LIU, Z., HAO, H. The impact of fuel cell vehicle deployment on road transport greenhouse gas emissions: the China case. International Journal of Hydrogen Energy [online]. 2018, 43(50), p. 22604-22621. ISSN 0360-3199. Available from: https://doi.org/10.1016/j.ijhydene.2018.10.088

[34] NATR, L. Earth like a glass: why are you afraid of $\mathrm{CO}_{2 \text { ? }}$ (In Czech). Praha: Academia, 2006. ISBN 80-200-1362-8.

[35] United Nations framework convention on climate change - Ministry of the Environment of the Czech Republic [online]. 2014. Available from: https://www.mzp.cz/en/climate_energy

[36] CICHOSZ, M., PLUTA-ZAREMBA, A. How to improve freight transport emissions management? Logforum [online]. 2019, 15(1), p. 93-105. ISSN 1734-459X. Available from: https://doi.org/10.17270/J.LOG.2019.312

[37] ERIKSSON, L., NIELSEN, L. Modelling and control of engines and drivelines [online]. Chennai, India: John Wiley and Sons, 2014. ISBN 978-1-118-47999-5. Available from: https://doi.org/10.1002/9781118536186.fmatter

[38] FINK, A. Conducting research literature reviews: from the internet to paper. Los Angeles: Sage, 2014. ISBN 978-1-452-25949-9. 
[39] PETTICREW, M., ROBERTS, H. Systematic reviews in the social sciences: a practical guide. Oxford: John Wiley \& Sons, 2008. ISBN 978-1-405-12110-1.

[40] REZAZADEH, F., PARIA, D., JAFARPOUR, D. Laser effects on the prevention and treatment of dentinal hypersensitivity: a systematic review. Journal of Lasers in Medical Sciences [online]. 2019, 10(1), p. 1-11. I SSN 2008-9783, eISSN 2228-6721. Available from: https://doi.org/10.15171/jlms.2019.01

[41] ENGELEN, L., CHAU, J., YOUNG, S., MACKEY, M., JEYAPALAN, D., BAUMAN, A. Is activity-based working impacting health, work performance and perceptions? A systematic review. Building Research and Information [online]. 2019, 47(4), p. 468-479. ISSN 0961-3218, eISSN 1466-4321. Available from: https://doi.org/10.1080/09613218.2018.1440958

[42] PERERA, H.-N., HURLEY, J., FAHIMNIA, B., REISI, M. The human factor in supply chain forecasting: a systematic review. European Journal of Operational Research [online]. 2019, 274(2), p. 574-600. ISSN 0377-2217. Available from: https://doi.org/10.1016/j.ejor.2018.10.028

[43] KRIPPENDORFF, K. Content analysis: an introduction to its methodology. Thousand Oaks: Sage Publications, 2003. ISBN 978-0761915447.

[44] SOUlE, E. K., SAKUMA, K.-L. K., PALAFOX, S., POKHREL, P., HERZOG, T. A., THOMPSON, N., FAGAN, P. Content analysis of internet marketing strategies used to promote flavored electronic cigarettes. Addictive Behaviors [online]. 2019, 91, p. 128-135. ISSN 0306-4603, eISSN 1873-6327. Available from: https://doi.org/10.1016/j.addbeh.2018.11.012

[45] SOLDATENKO, D., BACKER, E. A content analysis of cross-cultural motivational studies in tourism relating to nationalities. Journal of Hospitality and Tourism Management [online]. 2019, 38, p. 122-139. ISSN 1447-6770. Available from: https://doi.org/10.1016/j.jhtm.2018.12.004

[46] KRAJEWSKI, J. M. T., SCHUMACHER, A. C., DALRYMPLE, K. E. Just turn on the faucet: a content analysis of PSAs about the global water crisis on YouTube. Environmental Communication [online]. 2019, 13(2), p. 255-275. ISSN 1752-4032, eISSN 1752-4040. Available from: https://doi.org/10.1080/17524032.2017.1373137

[47] RAGIN, CH. C. The comparative method: moving beyond qualitative and quantitative strategies. Oakland: University of California Press, 1987. ISBN: 978-0-520-28003-8.

[48] $\mathrm{CO}_{2}$ emission calculator - EECA Business [online]. [Viewed 2019-01-03]. Available from: https://www.eecabusiness. govt.nz/tools/wood-energy-calculators/co2-emission-calculator/

[49] Emission calculator and carbon offset - SAS [online]. [Viewed 2019-01-05]. Available from: https://www.sasgroup.net/ en/emission-calculator-and-carbon-offset/

[50] Emissions calculator - Cargolux [online]. [Viewed 2019-01-06]. Available from: https://www.cargolux.com/OurExpertise/e-services/Emissions-Calculator

[51] Business $\mathrm{CO}_{2}$ emissions calculator - ClimateCare [online]. [Viewed 2019-01-08]. Available from: http://www.climatecare. org/business/business-co2-calculator/

[52] Freight emissions calculator - Delivered GrEAn [online]. [Viewed 2019-01-10]. Available from: http://www.freightemissionscalculator.com/

[53] Ship type carbon emissions calculator - Sustainable freight [online]. [Viewed 2019-01-12]. Available from: http://www.sustainablefreight.com.au/tools-and-programs/emission-calculators/ship-type-carbon-emissions-calculator

[54] Calculation - EcoTransIT World [online]. [Viewed 2019-01-13]. Available from: https://www.ecotransit.org/calculation. en.html

[55] $\mathrm{CO}_{2}$ calculator - Van Donge \& De Roo Group [online]. [Viewed 2019-01-16]. Available from: https://www.vandongederoo. com/co2-calculator/

[56] OOCL carbon calculator - Orient Overseas Container Line [online]. [Viewed 2019-01-19]. Available from: https://www.oocl.com/eng/aboutoocl/Environmentalcare/ooclcarboncalculator/Pages/default.aspx

[57] Carbon calculator - Canadian National Railway Company [online]. [Viewed 2019-01-24]. Available from: https://www.cn.ca/en/delivering-responsibly/environment/emissions/carbon-calculator/ 